\title{
Occurrence of Escherichia coli in the Cuyahoga River in the Cuyahoga Valley National Park, Ohio
}

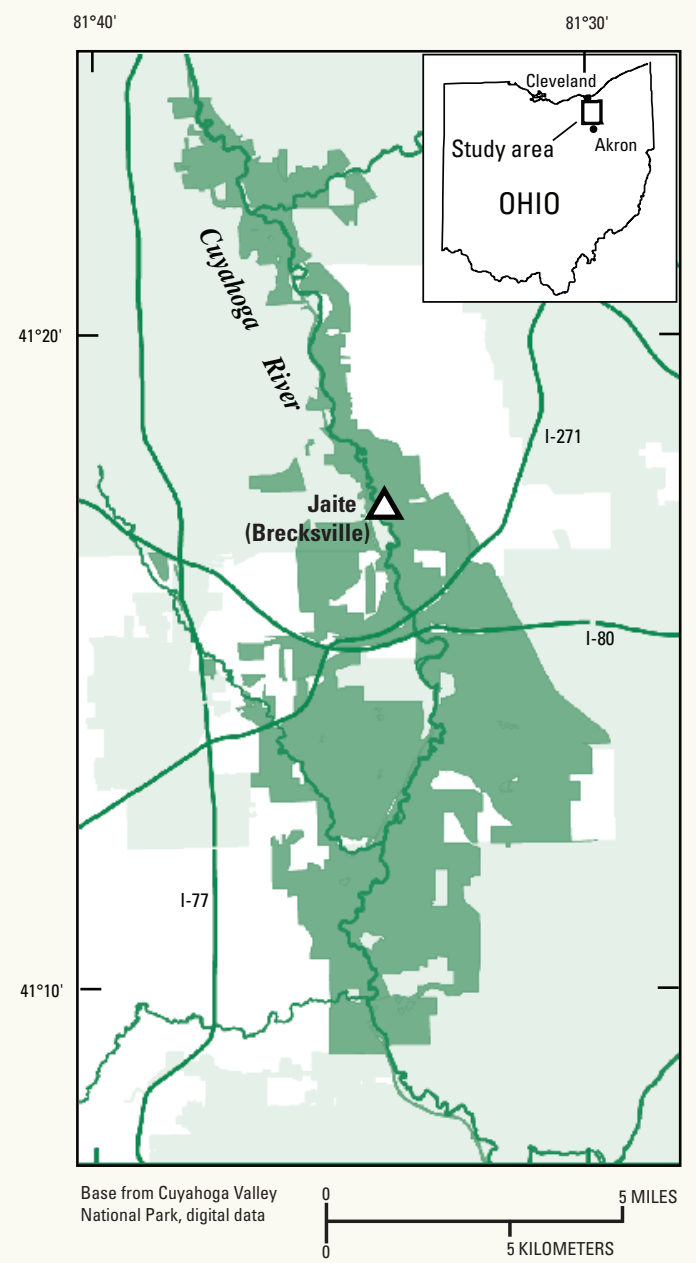

EXPLANATION

\section{Why is Escherichia coli Important?}

There are several measures of the "cleanliness" of a natural body of water, including concentrations of indicator bacteria, anthropogenic chemicals (chemicals derived from human activities), and nutrients, such as nitrogen and phosphorous. Escherichia coli (E. coli) is a bacterium that lives in the intestinal tract of warm-blooded animals, such as humans, deer, cows, and dogs. Most strains of E. coli are not harmful and are in fact beneficial to humans by aiding in the digestive process. A few strains, such as the O157 strain, produce toxins that can cause gastrointestinal illness, but occurrence of toxic strains in the environment is not common. E. coli is considered a good indicator bacterium because its occurrence in the environment indicates the presence of fecal contamination and therefore the possible presence of pathogenic organisms associated with feces.

The U.S. Environmental Protection Agency (USEPA) recommends using measurements of $E$. coli to monitor freshwaters and set criteria for the concentration of bacteria that can be present in the water with minimal adverse human-health effects. Typically, a State's waters are assigned a recreational-use designation, such as bathing, primary-contact, or secondarycontact waters (in the box below), which is used to set the State's water-quality standards based on the USEPA criteria. The Cuyahoga River in the Cuyahoga Valley National Park (fig. 1) is designated for primary-contact recreation; therefore, when concentrations of $E$. coli exceed $298 \mathrm{CFU} / 100 \mathrm{~mL}$ (see box below), the river would be considered potentially unsafe for recreation.

Approximate area of park

Urban area

$\triangle$ Sampling site

Figure 1. Map of Cuyahoga Valley National Park with sampling location.

\section{Use Designation Definitions for Ohio Waters}

[CFU/100mL, colony-forming units per 100 milliliters]

Bathing waters: waters that are suitable for swimming where a lifeguard and (or) bathhouse facilities are present; E. coli single-sample standard is $235 \mathrm{CFU} / 100 \mathrm{~mL}$.

Primary-contact: waters that are suitable for full-body contact recreation, such as swimming, canoeing, and scuba diving; E. coli single-sample standard is $298 \mathrm{CFU} / 100 \mathrm{~mL}$.

Secondary-contact: waters that are suitable for partial-body contact recreation, such as wading; E. coli single-sample standard is $576 \mathrm{CFU} / 100 \mathrm{~mL}$. 


\section{How is Escherichia coli Detected in Water Samples?}

The time required to determine concentrations of $E$. coli using current (2010) USEPA-approved methods is 18 to 24 hours. A liquid- or solid-growth medium provides nutrients that allow E. coli to grow and multiply during incubation at warm temperatures. After the USEPA-mandated incubation period, $E$. coli can be visualized and counted to determine concentrations. Because water quality can change within the timeframe required to obtain results, however, results obtained from analysis of the previous day's sample, which are used to determine when alerts are issued, may not be indicative of real-time conditions. The result may be lost recreational opportunities or - even more undesirable - unintended exposure to waters that do not meet recreational standards if an alert is warranted but not issued.

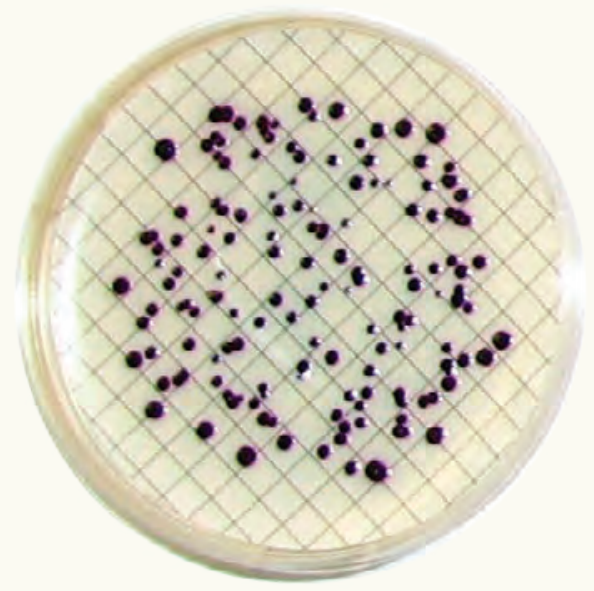

Photograph of modified mTEC agar plate with bacterial growth (Escherichia coli colonies are shown in magenta.)

\section{Has Escherichia coli Been Detected in the Cuyahoga River in the Cuyahoga Valley National Park?}

The U.S. Geological Survey (USGS), in cooperation with the Cuyahoga Valley National Park, has completed several studies evaluating concentrations of $E$. coli in the Cuyahoga River. During 1991-93, field studies indicated that concentrations of $E$. coli were elevated and the natural processes of decay and dispersion would be insufficient to reduce the concentrations below recreational water-quality standards in frequently visited reaches of the river (Myers and others, 1998). Research done during 2000 and 2002 (Bushon and Koltun, 2004) indicated that pathogenic microorganisms were detected more often in samples with concentrations of $E$. coli elevated above the single-sample standard for secondary-contact recreation than in samples with concentrations that were below the standard. During 2004-09, research focused on developing more efficient methods to predict same-day concentrations of $E$. coli (Brady, 2007; Brady and others, 2009; Brady and Plona, 2009; Bushon and others, 2007). An easily measured water-quality characteristic, turbidity, was found to rise and fall with concentrations of E. coli in the Cuyahoga River (fig. 2). Turbidity, or the cloudiness of the water, is measured with an instrument called a turbidimeter. Statistical models that use turbidity to predict concentrations of $E$. coli in the Cuyahoga River were developed and tested at the Cuyahoga Valley National Park.

\section{How Can Models Be Used to Determine When Water in the Cuyahoga Valley National Park Is Unsafe for Recreation?}

Data were collected for several years prior to development of a statistical model to ensure that a broad range of environmental conditions is represented in the model. Then, researchers examine the data for environmental and (or) waterquality characteristics or constituents (explanatory variables) that tend to rise or fall with, or in contrast to, the concentration of E. coli. Models are developed using a standard statistical technique called linear regression, in which the relation of one water-quality characteristic or constituent to another is determined. After selecting the variables that best predict concentrations of $E$. coli, the model can be used to calculate estimates of the concentration of E. coli for the current day.

There are two ways to predict whether the quality of water in the river will be above or below the State standard for recreational use. The predicted concentration of $E$. coli can be compared to the State standard to determine whether the water body likely is safe or unsafe for recreation; however, the predicted concentrations of $E$. coli tend to vary widely, and may not be the best means for predicting whether a water body is suitable for recreational use. As an alternative, the probability that the concentration of $E$. coli will exceed the standard on a given day can be calculated (Francy and others, 2003). This method is similar to a weather forecast, when a meteorologist predicts the likelihood of rainfall (for example, a 60-percent chance of rainfall). To determine whether the water body is safe or unsafe for recreation, a threshold probability is used to ensure that the number of correct predictions is maximized and the number of incorrect predictions is minimized. If the probability of exceeding the State standard for that day is above the threshold probability, then the water body is considered unsuitable for recreation. 


\section{Where Can I Find More information?}

During the 2009 recreational season (May-August), the Ohio Nowcast web site (www.OhioNowcast.info) was used to provide public access to same-day predictions of the recreational water quality of the Cuyahoga River at a site centrally located within the Cuyahoga Valley National Park (Jaite, at Vaughn Road, Brecksville, Ohio) (fig. 1). This service is expected to continue during upcoming recreational seasons.

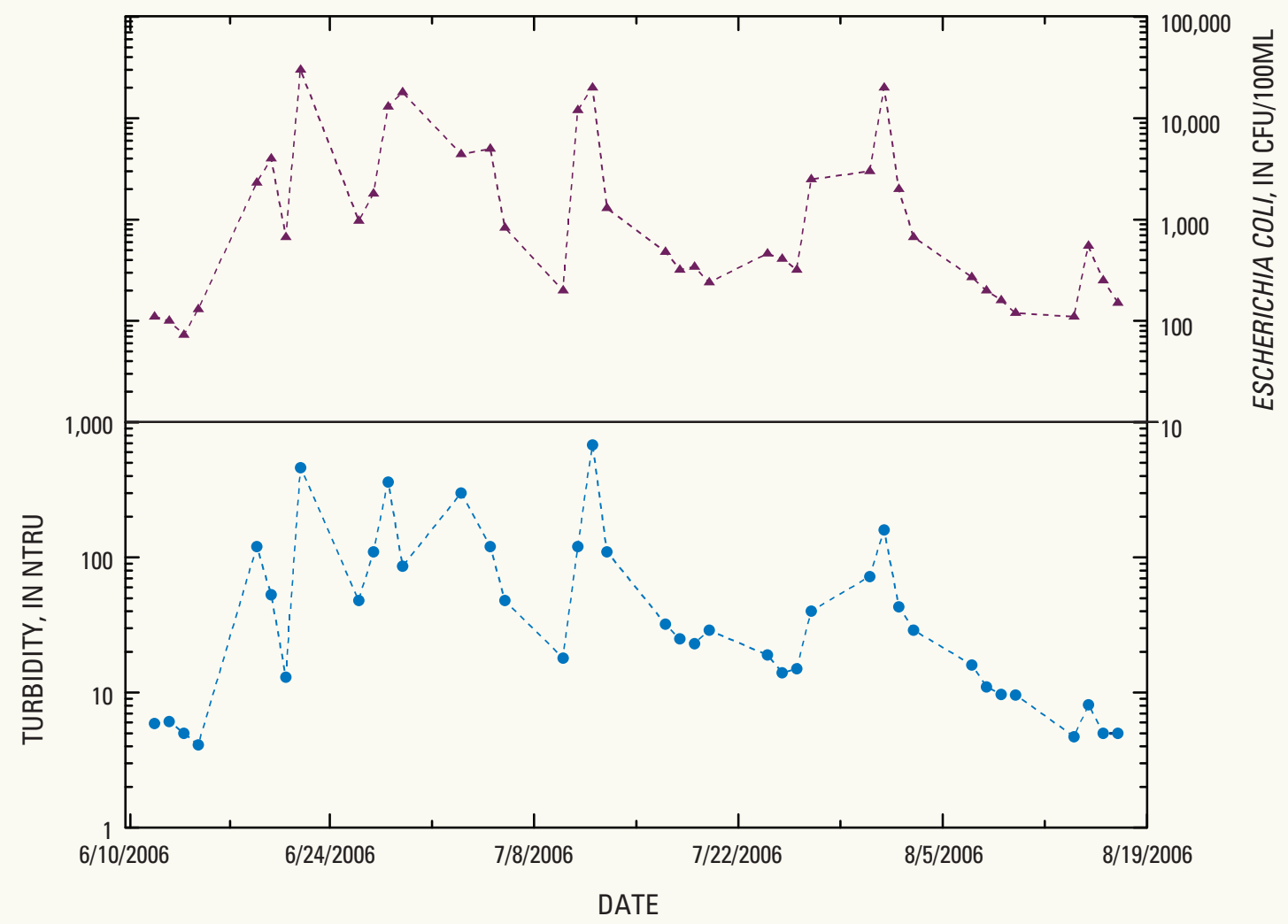

Figure 2. Escherichia coli and turbidity in the Cuyahoga River at Jaite (Brecksville, Ohio), Cuyahoga Valley National Park, 2006. The dashed lines are used for comparative purposes only and are not intended to imply that the variables were measured continuously. (CFU/100mL, colony-forming units per 100 milliliters; NTRU, nephelometric turbidity ratio unit).

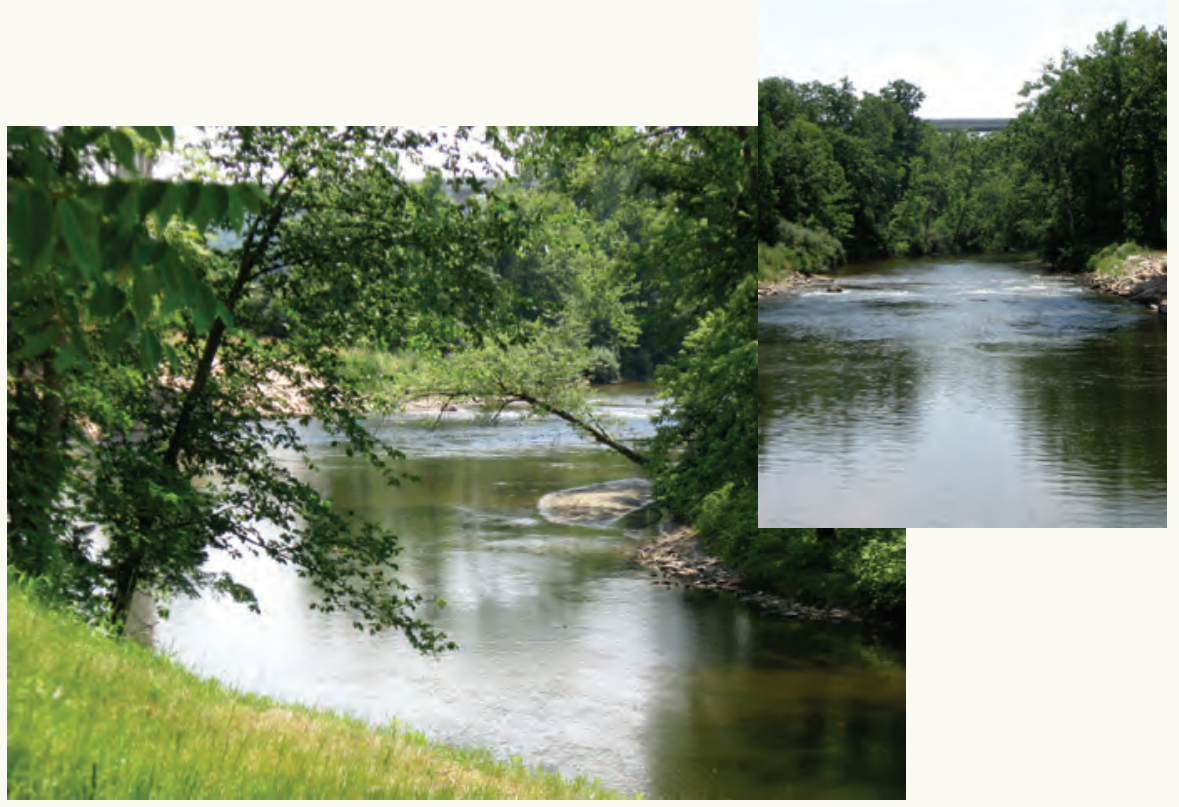

Cuyahoga River at Boston Mills Road, Peninsula Ohio

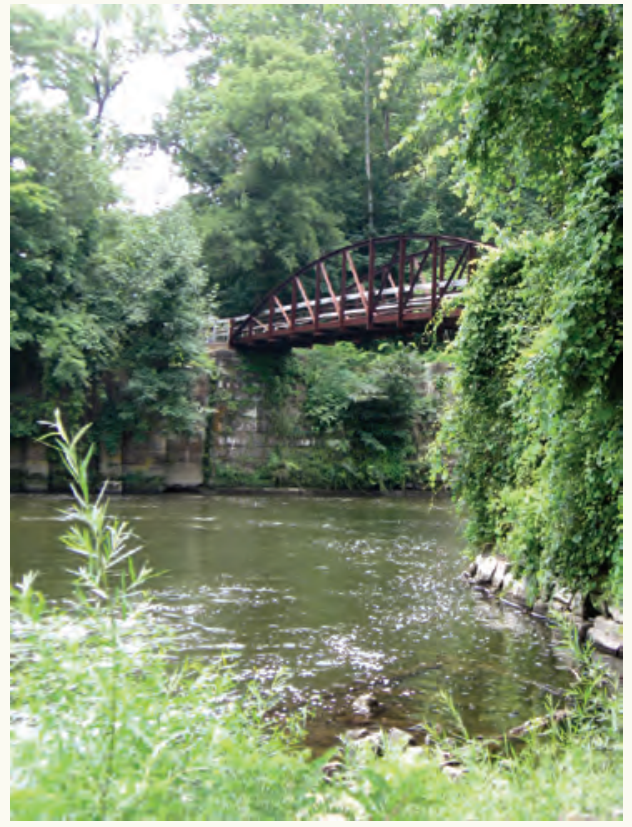

Lock 29 bridge over the Cuyahoga River, Peninsula Ohio 
